\title{
Immobilization and phytotoxicity reduction of heavy metals in serpentine soil using biochar
}

\author{
I. Herath • P. Kumarathilaka • A. Navaratne • \\ N. Rajakaruna $\cdot$ M. Vithanage
}

\begin{abstract}
Purpose Serpentine soils derived from ultramafic rocks release elevated concentrations of toxic heavy metals into the environment. Hence, crop plants cultivated in or adjacent to serpentine soil may experience reduced growth due to phytotoxicity as well as accumulate toxic heavy metals in edible tissues. We investigated the potential of biochar (BC), a waste byproduct of bioenergy industry in Sri Lanka, as a soil amendment to immobilize $\mathrm{Ni}, \mathrm{Cr}$, and $\mathrm{Mn}$ in serpentine soil and minimize their phytotoxicity.

Materials and methods The BC used in this study was a waste byproduct obtained from a Dendro bioenergy industry in Sri Lanka. This BC was produced by pyrolyzing Gliricidia sepium biomass at $900{ }^{\circ} \mathrm{C}$ in a closed reactor. A pot experiment was conducted using tomato plants (Lycopersicon esculentum L.) by adding $1,2.5$, and $5 \%(w / w)$ BC applications to evaluate the bioavailability and uptake of metals in serpentine soil. Sequential extractions were utilized to evaluate the effects of $\mathrm{BC}$ on bioavailable concentrations of $\mathrm{Ni}, \mathrm{Cr}$, and $\mathrm{Mn}$ as well as different metal fractionations in $\mathrm{BC}$ amended and BC-unamended soil. Postharvest soil in each
\end{abstract}

Responsible editor: Yong Sik Ok

I. Herath $\cdot$ P. Kumarathilaka $\cdot$ M. Vithanage $(\bowtie)$

Chemical and Environmental Systems Modeling Research Group, Institute of Fundamental Studies, Kandy 20000, Sri Lanka

e-mail: meththikavithanage@gmail.com

\author{
A. Navaratne \\ Department of Chemistry, University of Peradeniya, Kandy 20000, \\ Sri Lanka \\ N. Rajakaruna \\ College of the Atlantic, Bar Harbor, ME 04609, USA \\ N. Rajakaruna \\ Unit for Environmental Sciences and Management, North-West \\ University, Private Bag X6001, Potchefstroom 2520, South Africa
}

pot was subjected to a microbial analysis to evaluate the total bacterial and fungal count in BC-amended and BCunamended serpentine soil.

Results and discussion Tomato plants grown in $5 \% \mathrm{BC}$ amended soil showed approximately 40 -fold higher biomass than that of $\mathrm{BC}$-unamended soil, whereas highly favorable microbial growth was observed in the $2.5 \% \mathrm{BC}$-amended soil. Bioaccumulation of $\mathrm{Cr}, \mathrm{Ni}$, and $\mathrm{Mn}$ decreased by 93 $97 \%$ in tomato plants grown in $5 \%$ BC-amended soil compared to the BC-unamended soil. Sequentially extracted metals in the exchangeable fraction revealed that the bioavailabile concentrations of $\mathrm{Cr}, \mathrm{Ni}$, and $\mathrm{Mn}$ decreased by 99,61 , and $42 \%$, respectively, in the $5 \%$ BC-amended soil. Conclusions Results suggested that the addition of $\mathrm{BC}$ to serpentine soil as a soil amendment immobilizes $\mathrm{Cr}, \mathrm{Ni}$, and $\mathrm{Mn}$ in serpentine soil and reduces metal-induced toxicities in tomato plants.

Keywords Bioavailability $\cdot$ Chemisorption $\cdot$ Metal immobilization $\cdot$ Sequential extraction $\cdot$ Serpentine

\section{Introduction}

Heavy metal contamination of soil due to anthropogenic and non-anthropogenic activities is a widespread environmental problem with serious consequences for agricultural crop productivity and human health (Neilson and Rajakaruna 2014). Ultramafic rocks and related soils and sediments are nonanthropogenic sources of metal contamination (Rajakaruna and Baker 2004). Serpentine soils, derived from the weathering of ultramafic rocks, may release elevated concentrations of heavy metals such as nickel (Ni), chromium $(\mathrm{Cr})$, manganese $(\mathrm{Mn})$, and cobalt $(\mathrm{Co})$ into the environment (Rajapaksha et al. 2012; Vithanage et al. 2014a). In parts of northwestern Spain (Fernández et al. 1999), Canada (Baugé 
et al. 2013), Philippines (Susaya et al. 2010), and Japan (Kayama et al. 2002), where serpentine-associated soils are often subjected to agriculture and forestry, soils are intensively managed to make them amenable for plant growth.

Although these practices have allowed the growth of some plants, those growing on serpentine soils can accumulate high concentrations of toxic metals such as $\mathrm{Cr}, \mathrm{Ni}$, and $\mathrm{Mn}$ in their edible parts (Fernández et al. 1999; Susaya et al. 2010). Hence, the cultivation of crop plants in areas within and adjacent to serpentine outcrops and other heavy metalenriched sites may be of particular concern due to both phytotoxicity and metal accumulation (Neilson and Rajakaruna 2014). The prolonged consumption of metal-accumulating plants such as Zea mays L. (Almaroai et al. 2014), Allium sativum L. (Jiang et al. 2001), and Brassica napus L. (Houben et al. 2013a) may pose serious health risks when their consumption leads to concentrations above the toxicity threshold (Anderson et al. 2005), even for micronutrient metals such as $\mathrm{Cu}, \mathrm{Mn}$, and $\mathrm{Zn}$. Therefore, the restoration of such heavy metal rich soils using novel and economically feasible technologies is an urgent necessity before they are used in agriculture (Neilson and Rajakaruna 2014; Rajakaruna et al. 2006).

Because of the drawbacks of conventional soil remediation technologies such as soil replacement, solidification, electrokinetic extraction, and washing strategies (Mulligan et al. 2001; Sruthy and Jayalekshmi 2014), a considerable interest has been expressed in the use of a variety of biowastes such as woodchips, peanut shells, chicken manure, cow bone, eggshell, and poultry manure to remediate heavy metalcontaminated soils (Almaroai et al. 2014; Usman et al. 2013). Recently, carbon-rich amendments such as biochar (BC) have been used as an alternative and economically viable strategy to immobilize bioavailable toxic metals and reduce the phytotoxicity of heavy metals in contaminated soils (Almaroai et al. 2014; Houben et al. 2013a; Houben et al. 2013b).

$\mathrm{BC}$ is a carbon-rich product that is produced by pyrolyzing biowaste materials. It is capable of improving physical, chemical, and biological properties in soils due to its high organic carbon content (Almaroai et al. 2014). The application of BC as a soil amendment leads to increases in soil fertility and enhances plant growth by supplying and retaining essential nutrients while improving soil physical and biological properties (Houben et al. 2013b). The positive effects of BC on the immobilization of bioavailable heavy metals in contaminated soils have been investigated under greenhouse conditions (Houben et al. 2013a; Houben et al. 2013b; Park et al. 2011; Uchimiya et al. 2011). A commercial grade BC produced from Miscanthus straw has been successfully applied to contaminated soils for investigating the bioavailability of $\mathrm{Cd}, \mathrm{Pb}$, and $\mathrm{Zn}$ and the production of rapeseed (B. napus L.) biomass (Houben et al. 2013b). This study found that the addition of
$\mathrm{BC}$ as a soil amendment reduces the bioavailability of $\mathrm{Cd}, \mathrm{Pb}$, and $\mathrm{Zn}$ and provides a viable alternative and a cost-effective strategy to promote revegetation and restoration of heavy metal-contaminated lands as well as the growth of agricultural crops. Arsenic (As) concentrations in soil, soil pore water, and plant tissues were evaluated in a pot experiment following the transplantation of tomato (Solanum lycopersicum L.) plants to a heavily As-contaminated mine soil amended with an orchard prune residue BC (Beesley et al. 2013). Biochar significantly increased As concentrations in soil pore water, while root and shoot concentrations were significantly reduced compared to the control without BC. Fruit As concentrations were very low, indicating minimal toxicity and transfer risk. In a study conducted by Park et al. (2011), application of BC derived from green waste to shooting range and spiked soils significantly immobilized and reduced the phytoavailability of $\mathrm{Cd}$, $\mathrm{Pb}$, and $\mathrm{Cu}$ in Indian mustard (Brassica juncea (L.) Czern.) plants. Moreover, a recent study demonstrated that bur cucumber-derived $\mathrm{BC}$ was effective in reducing the mobility of sulfamethazine (SMZ) in agricultural soils (Vithanage et al. 2014b). Similar to the benefits, the limitations and draw backs of the use of $\mathrm{BC}$ for the remediation of contaminated soils are also of particular concern. Although in short-term experiments of months to a few years, $\mathrm{BC}$ could be seen to enhance plant growth and soil nutrient status, neither the quantitative variability in response nor the durability of the effects is specified. Moreover, the addition of BC to soil in excessive levels may cause detrimental impacts on soil structure and pose serious consequences for the growth of crop plants. Hence, the potential limitations and drawbacks of the use of $\mathrm{BC}$ may be encountered at large-scale and long-term deployment in field.

The presence of excessive metal content in soils surrounding disturbed serpentine and other naturally metal-enriched systems may have serious consequences for groundwater and agricultural productivity; however, not many attempts have been made to remediate such sites for effective cultivation. Remediation of sites adjacent to metal-enriched settings can provide much-needed land for the cultivation of plants to use as food or animal feed. Hence, this study investigated the potential of waste woody BC from a bioenergy plant as a soil amendment to immobilize bioavailable toxic metals and reduce the phytotoxicity of heavy metals. Specifically, we examined whether this woody BC is capable of effectively immobilizing and reducing the phytotoxicity of $\mathrm{Ni}, \mathrm{Cr}$, and $\mathrm{Mn}$ in serpentine soil. We assessed how the application of different rates of $\mathrm{BC}$ to serpentine soil can influence the immobilization of $\mathrm{Ni}, \mathrm{Cr}$, and $\mathrm{Mn}$ found in serpentine soil and thereby reduce phytotoxicity in tomato plants (Lycopersicon esculentum L; Solanaceae) grown under greenhouse conditions. Tomato plants were selected for this study as this species has received much attention due to its cultivation as a crop plant in areas adjacent to metal-enriched serpentine outcrops in Sri Lanka. 


\section{Materials and methods}

\subsection{Serpentine soil}

Serpentine soil was collected from the top $0-15 \mathrm{~cm}$ of soil from the Wasgamuwa area (Yudhaganawa serpentine outcrop), Sri Lanka (Rajapaksha et al. 2012; Vithanage et al. 2014a) for use in this study. Soil samples were air-dried and mechanically sieved to $<2 \mathrm{~mm}$ of particle size prior to use in the laboratory and greenhouse experiments. Basic properties of this serpentine soil are summarized in Table 1.

\subsection{Biochar}

The BC used in this study was a waste byproduct from a bioenergy industry (Dendro) at Thiruppane, Anuradhapura District, Sri Lanka. This BC was produced by pyrolyzing the woody biomass (BM), Gliricidia sepium (Jacq.) Steud. (Fabaceae) in a closed reactor. The end temperature of this process was recorded as $900{ }^{\circ} \mathrm{C}$ at which Gliricidia wood is gasified for the generation of electricity. The $\mathrm{BC}$ obtained from this power plant was air-dried and ground in a blender and sieved to $<1 \mathrm{~mm}$ of particle size prior to use in the experiments.

\subsection{Biochar characterization}

All chemicals used were analytical grade and purchased from Fluka (Switzerland) or Sigma (USA). This woody BC was tested for $\mathrm{pH}$, electrical conductivity (EC), ash, moisture, volatile matter content, total organic carbon (TOC), cation exchange capacity (CEC), elemental composition, surface area, and Fourier transform infrared (FTIR) spectra. $\mathrm{pH}$ and $\mathrm{EC}$ in $\mathrm{BC}$ were measured in 1:5 suspensions of $\mathrm{BC}$-to-water

Table 1 Total and exchangeable metal concentrations of serpentine soil

\begin{tabular}{ll}
\hline Parameter & Value \\
\hline Total metal digestion $\left(\mathrm{mg} \mathrm{kg}^{-1}\right)$ & \\
$\mathrm{Ni}$ & $6,567 \pm 3.08$ \\
$\mathrm{Cr}$ & $14,880 \pm 6.14$ \\
$\mathrm{Mn}$ & $2,609 \pm 2.83$ \\
Exchangeable Ni $\left(\mathrm{mg} \mathrm{kg}^{-1}\right)$ & \\
$\quad$ With distilled water & $7.4 \pm 0.07$ \\
$\quad$ With 0.01 CaCl & \\
Exchangeable $\mathrm{Cr}_{2}\left(\mathrm{mg} \mathrm{kg}^{-1}\right)$ & $211.9 \pm 0.16$ \\
$\quad$ With distilled water & $\mathrm{ND}$ \\
$\quad$ With $0.01 \mathrm{CaCl}_{2}$ & $12.5 \pm 0.03$ \\
Exchangeable $\mathrm{Mn}\left(\mathrm{mg} \mathrm{kg}^{-1}\right)$ & \\
$\quad$ With distilled water & $0.79 \pm 0.05$ \\
$\quad$ With $0.01 \mathrm{CaCl}_{2}$ & $11.2 \pm 0.14$ \\
\hline
\end{tabular}

using a digital pH meter (702SM Titrino, Metrohm) and an electrical conductivity meter (Orion 5 star meter, Thermo Scientific), respectively. Exchangeable $\mathrm{Ca}^{2+}, \mathrm{Mg}^{2+}, \mathrm{Na}^{+}$, and $\mathrm{K}^{+}$were extracted via the ammonium acetate procedure (Summer and Andersen 1996) and concentrations of metals were determined using an atomic absorption spectrophotometer (AAS, GBC933, Australia). The organic matter content was determined following the Walkley-Black method (Mebius 1960). Total $\mathrm{N}$ and other elements including $\mathrm{C}, \mathrm{O}$, $\mathrm{H}$, and $\mathrm{S}$ were analyzed using a $\mathrm{CHN}$ analyzer (Vario MAX $\mathrm{CN}$, elementar, Hanau, Germany). The surface area of BC was determined following the BET method (Peterson et al. 2012). The FTIR spectra of vacuum dried sample pellets, prepared with fused-KBr, were obtained with a resolution of $1 \mathrm{~cm}^{-1}$ between 4,000 and $400 \mathrm{~cm}^{-1}$ (Nicolet 6700, USA). The spectra were analyzed using OMNIC version 8.0 software, and the spectral data of Gliricidia BM and its BC derived at $900{ }^{\circ} \mathrm{C}$ are shown in Fig. 1. Moisture was determined by calculating the weight loss after heating the $\mathrm{BC}$ at $105{ }^{\circ} \mathrm{C}$ for $24 \mathrm{~h}$ to a constant weight. Mobile matter (analogous to volatile matter), which reflects the non-carbonized portion in $\mathrm{BC}$, was determined as the weight loss after heating in a covered crucible at $450{ }^{\circ} \mathrm{C}$ for $30 \mathrm{~min}$ (Ahmad et al. 2014). Ash content was also measured as the residue remaining after heating at $700{ }^{\circ} \mathrm{C}$ in an open-top crucible. The portion of the $\mathrm{BC}$ not ashed, referred to as resident matter (analogous to fixed matter), was calculated by the difference in moisture, ash, and mobile matter. Each sample was analyzed in triplicate. Table 2 summarizes the data obtained from proximate and ultimate analyses for this high temperature-derived $\mathrm{BC}$.

The surface area of this woody BC was $714 \mathrm{~m}^{2} \mathrm{~g}^{-1}$ (Table 2) which is extremely high compared to the surface area of soybean stover BC $\left(420.3 \mathrm{~m}^{2} \mathrm{~g}^{-1}\right)$, and peanut shell $\mathrm{BC}\left(448.2 \mathrm{~m}^{2} \mathrm{~g}^{-1}\right)$ produced at $700{ }^{\circ} \mathrm{C}$ (Ahmad et al. 2012). Elemental analyses revealed that the low molar $\mathrm{O} / \mathrm{C}$ ratio is due to high pyrolytic temperature as the surfaces of hightemperature BC become less hydrophilic (Ahmad et al. 2012). Atomic ratios $\mathrm{H} / \mathrm{C}$ and $[(\mathrm{O}+\mathrm{N}) / \mathrm{C}]$ are recognized as indices for aromaticity and polarity of $\mathrm{BC}$, respectively (Ahmad et al. 2013; Chen et al. 2008). Lower values of both $\mathrm{H} / \mathrm{C}$ and the polarity index $[(\mathrm{O}+\mathrm{N}) / \mathrm{C}]$ ratios of the $\mathrm{BC}$ indicated that the high temperature-derived $\mathrm{BC}$ are highly carbonized, exhibiting a highly aromatic structure (Ahmad et al. 2013). The reduction of $\mathrm{O} / \mathrm{C}$ and $\mathrm{H} / \mathrm{C}$ ratios is mainly due to dehydratation, decarboxylation, and decarbonylation processes during pyrolysis at higher temperatures (Sun et al. 2012). Furthermore, the concentrations of $\mathrm{N}$ and $\mathrm{S}$ were quite low, implying that even if they were to be burnt as the feedstock for $\mathrm{BC}$ production, they may give off only low rates of nitrogen oxide and sulfur oxide to the environment.

In the FTIR spectra (Fig. 1), the broad peak observed at $3,356 \mathrm{~cm}^{-1}$ in $\mathrm{BM}$ corresponds to the stretching vibration of 
Fig. 1 FTIR spectra of the biomass of Gliricidia (BM) and its biochar (BC) derived at $900{ }^{\circ} \mathrm{C}$

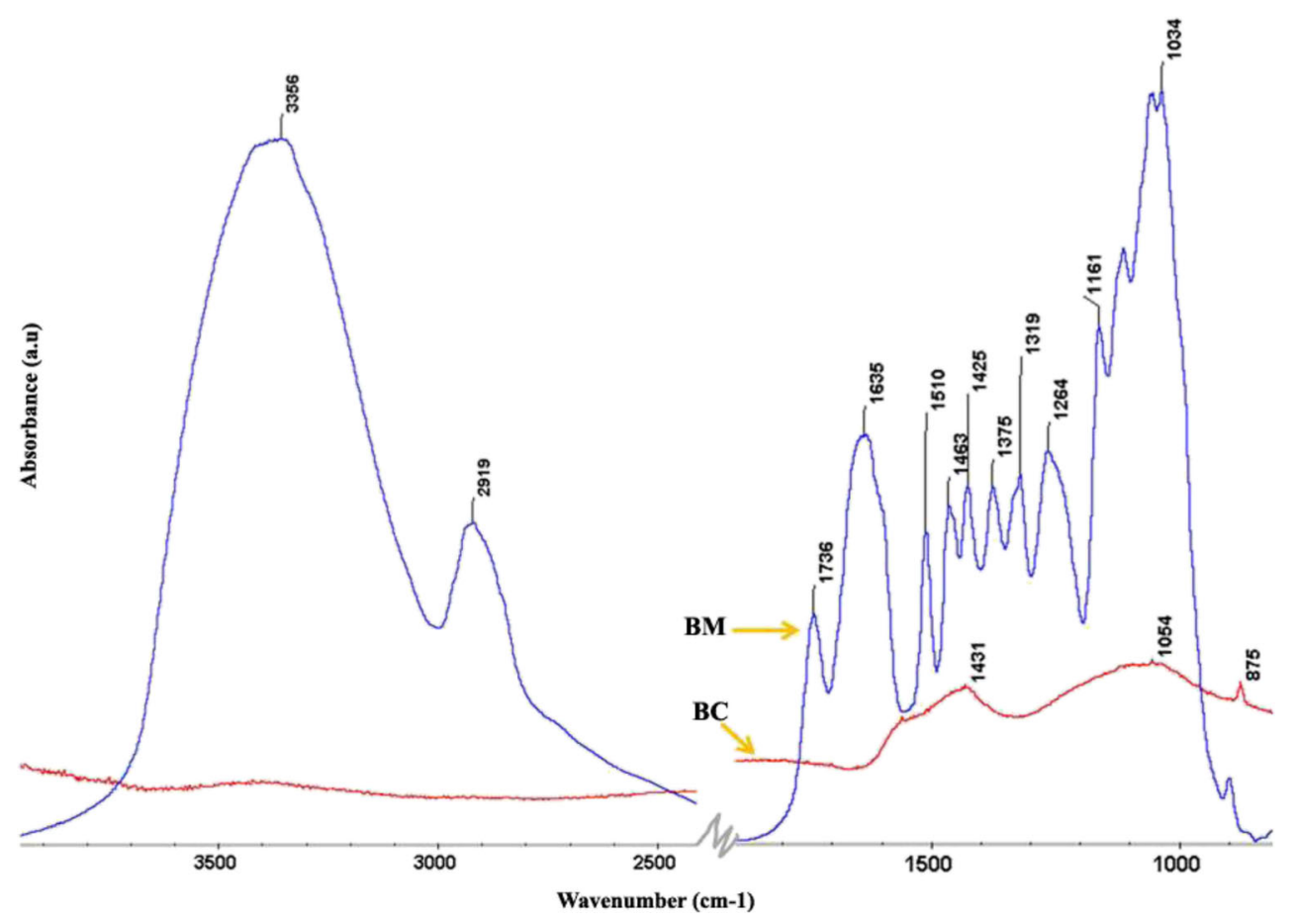

- OH group, indicating the presence of bonded water (Ahmad et al. 2014; Chen et al. 2008). The band intensity is markedly reduced in $\mathrm{BC}$ due to the elimination of water molecules and other volatile functional groups as a result of higher temperature. The peaks at 2,919,1,463, and $1,375 \mathrm{~cm}^{-1}$ in BM are assigned mainly to $\mathrm{CH}_{2}$ stretching vibration, suggesting the presence of long-linear aliphatic groups in $\mathrm{BM}$ which are completely eliminated in BC (Chen et al. 2008). This suggests the removal of nonpolar functional groups during pyrolysis. The band at $1,635 \mathrm{~cm}^{-1}$ corresponds to the lignin content of $\mathrm{BM}$, and its disappearance in BC suggests the loss of the original plant structure of Gliricidia (Chen et al. 2008). Peaks at 1,736 and $1,510 \mathrm{~cm}^{-1}$ in $\mathrm{BM}$ are assigned to $\mathrm{C}=\mathrm{O}$ stretching in the aromatic ring and $\mathrm{C}=\mathrm{C}$ ring stretching vibration of lignin, respectively (Chen et al. 2008). The peak of $875 \mathrm{~cm}^{-1}$ in $\mathrm{BC}$ is assigned to the aromatic $\mathrm{CH}$ out-of-plane deformation condensing smaller aromatic units into larger sheets (Ahmad et al. 2014; Chen et al. 2008). The band at $1,264 \mathrm{~cm}^{-1}$ indicates the aromatic $\mathrm{CO}-$ and phenolic- $\mathrm{OH}$ stretching, and it is completely eliminated in $\mathrm{BC}$ (Chen et al. 2008). The bands due to aliphatic $\mathrm{C}-\mathrm{O}-\mathrm{C}$ and alcohol- $\mathrm{OH}$ $\left(1,161-1,034 \mathrm{~cm}^{-1}\right)$ in BM indicate oxygenated functional groups (Chen et al. 2008). Appearance of new peaks at 1,431 and $1,054 \mathrm{~cm}^{-1}$ in $\mathrm{BC}$ are assigned to $\mathrm{CO}_{3}{ }^{-2}$ and $=\mathrm{S}=\mathrm{O}$ (sulfoxides), respectively. The overall interpretation of the spectra suggested the dehydration of cellulosic and ligneous contents in the $\mathrm{BM}$ and an increase in the condensation of aromatic units in the $\mathrm{BC}$ produced at a high temperature.

\subsection{Pot experiment}

Untreated soil (control) and soil treated with three rates of BC applications were used in the experiment. Soil was amended by mixing dry $\mathrm{BC}$ with a mass fraction of $1,2.5$, and $5 \%(w /$ $w)$. Amended soils were thoroughly homogenized in large plastic containers prior to use. Plastic pots $(12.0 \mathrm{~cm}$ diameter, $9.0 \mathrm{~cm}$ height) were filled with $\sim 250 \mathrm{~g}$ of BC-amended and $\mathrm{BC}$-unamended soil and $100 \mathrm{~g}$ each of washed sand (to

Table 2 Proximate and ultimate analyses data for the $\mathrm{BC}$ derived at $900{ }^{\circ} \mathrm{C}$

\begin{tabular}{|c|c|c|c|c|c|c|c|c|}
\hline \multicolumn{9}{|c|}{ Proximate analysis } \\
\hline \multicolumn{2}{|c|}{$\mathrm{pH}$} & \multicolumn{2}{|l|}{$\begin{array}{l}\text { Moisture } \\
(\%)\end{array}$} & \multicolumn{2}{|c|}{$\begin{array}{l}\text { Mobile matter } \\
(\%)\end{array}$} & \multicolumn{2}{|l|}{$\begin{array}{l}\text { Ash } \\
(\%)\end{array}$} & $\begin{array}{l}\text { Resident matter } \\
\text { (\%) }\end{array}$ \\
\hline \multicolumn{2}{|c|}{$10.10 \pm 0.07$} & \multicolumn{2}{|l|}{$6.50 \pm 0.05$} & \multicolumn{2}{|c|}{$9.90 \pm 0.03$} & \multicolumn{2}{|l|}{$70 \pm 0.01$} & $63 . \pm 0.18$ \\
\hline \multicolumn{9}{|c|}{ Ultimate analysis } \\
\hline $\begin{array}{l}\mathrm{C} \\
(\%)\end{array}$ & $\begin{array}{l}\mathrm{H} \\
(\%)\end{array}$ & $\begin{array}{l}\mathrm{O} \\
(\%)\end{array}$ & $\begin{array}{l}\mathrm{N} \\
(\%)\end{array}$ & $\begin{array}{l}\mathrm{S} \\
(\%)\end{array}$ & $\begin{array}{l}\text { Molar } \\
\mathrm{H} / \mathrm{C}\end{array}$ & $\begin{array}{l}\text { Molar } \\
\mathrm{O} / \mathrm{C}\end{array}$ & $\begin{array}{l}\text { Molar } \\
{[(\mathrm{O}+\mathrm{N}) / \mathrm{C}]}\end{array}$ & $\begin{array}{l}\text { BET } \\
\text { Surface area } / \mathrm{m}^{2} \mathrm{~g}^{-1}\end{array}$ \\
\hline $50 \pm 0.12$ & $1 \pm 0.05$ & $44 \pm 0.02$ & $0.5 \pm 0.01$ & $0.1 \pm 0.03$ & $0.02 \pm 0.001$ & $0.88 \pm 0.002$ & $0.89 \pm 0.002$ & $714.00 \pm 0.85$ \\
\hline
\end{tabular}


prevent soil compaction). The pots were then placed in a dark room for the soil mixture to equilibrate over 2 weeks. Each treatment was performed in triplicate. After the equilibration period, the pots were transferred to an outdoor greenhouse and arranged in a randomized manner. In each pot, 25 seeds of tomato were sown and plants were grown for 9 weeks from June to August 2013. All pots were irrigated with $30 \mathrm{~cm}^{3}$ of tap water three times per week.

\subsection{Plant tissue analysis}

From each treatment, three whole plants per pot were harvested at six successive intervals from fourth to ninth week from germination. Whole plants were used as it was difficult to obtain enough biomass for metal analyses by separating shoots and roots. Harvested plants were thoroughly washed with tap water and rinsed with deionized water. After air drying in a forced draft oven at $60^{\circ} \mathrm{C}$ for $48 \mathrm{~h}$ and subsequent cooling in a desiccator, the dry weight of each plant was measured. The total amount of $\mathrm{Cr}, \mathrm{Ni}$, and $\mathrm{Mn}$ in plant tissue was analyzed by AAS after digestion with $10 \mathrm{~cm}^{3}$ of concentrated $\mathrm{HNO}_{3}$ acid in a closed-vessel temperature-controlled microwave digester system (Milestone ETHOS PLUS labstation with HRP-1000/10S high pressure segmented rotor).

\subsection{Soil analysis}

\subsubsection{Sequential extraction}

Sequential extractions involved the selective extraction of trace metals from soil solid fractions, providing detailed information on the availability of heavy metals among the different geochemical phases in soil (Paz-Ferreiro et al. 2013). Ideally, the extractants are chosen to selectively target a specific soil compartment with minimal dissolution of nontargeted phases. The sequential extraction procedure was carried out on both control and postharvest soils following the procedure described by Armienta et al. (1996). A mass of $1 \mathrm{~g}$ of soil (dry weight) was used for the initial extraction. A total of five replicate sequential extraction analyses were completed on the four soil treatments. The concentrations of $\mathrm{Ni}, \mathrm{Cr}$, and Mn were measured in the effluent after each extraction using AAS. Below is a list of the extraction procedures performed on the soil amendments.

(i) Exchangeable: Soil was reacted at room temperature for $1 \mathrm{~h}$ with $20 \mathrm{~cm}^{3}$ of magnesium chloride solution $(1 \mathrm{M}$ $\mathrm{MgCl}_{2}, \mathrm{pH}$ 7.0) with continuous agitation.

(ii) Bound to carbonates: Residue from (i) was leached at room temperature for $2 \mathrm{~h}$ with $20 \mathrm{~cm}^{3}$ of $1 \mathrm{M}$ sodium acetate $(\mathrm{NaOAc})$ adjusted to $\mathrm{pH} 5.0$ with acetic acid (HOAc) and with continuous agitation. (iii) Bound to $\mathrm{Fe}-\mathrm{Mn}$ oxide: Residue from (ii) was treated with $20 \mathrm{~cm}^{3}$ of $0.04 \mathrm{M}$ hydroxylamine hydrochloride $\left(\mathrm{NH}_{2} \mathrm{OH}-\mathrm{HCl}\right)$ in $25 \%(v / v)$ HOAc heated at $90{ }^{\circ} \mathrm{C}$ with slow continuous agitation for $2 \mathrm{~h}$.

(iv) Bound to organic matter: Residue from (iii) was treated with $3 \mathrm{~mL}$ of $0.02 \mathrm{M} \mathrm{HNO}_{3}$ and $5 \mathrm{~cm}^{3}$ of $30 \% \mathrm{H}_{2} \mathrm{O}_{2}$ adjusted to $\mathrm{pH} 2$ with $\mathrm{HNO}_{3}$, heated to $85^{\circ} \mathrm{C}$ for $2 \mathrm{~h}$ with occasional agitation. A $3 \mathrm{~cm}^{3}$ aliquot of $30 \% \mathrm{H}_{2} \mathrm{O}_{2}$ (pH 2 with $\mathrm{HNO}_{3}$ ) was added, and the sample was heated again to $85^{\circ} \mathrm{C}$ for $3 \mathrm{~h}$ with intermittent agitation. After cooling, $5 \mathrm{~cm}^{3}$ of $3.2 \mathrm{M} \mathrm{NH}_{4} \mathrm{OAc}$ in $20 \%(v / v)$ $\mathrm{HNO}_{3}$ was added and the sample was diluted to $20 \mathrm{~cm}^{3}$ and agitated continuously.

(v) Residual: Residue from (iv) was treated with a mixture of $10 \mathrm{~cm}^{3}$ concentrated $\mathrm{HF}$ and $2 \mathrm{~cm}^{3}$ concentrated $\mathrm{HClO}_{4}$ and heated to near dryness. It was then treated with $1 \mathrm{~cm}^{3}$ of $\mathrm{HClO}_{4}^{+}, 10 \mathrm{~cm}^{3}$ of $\mathrm{HF}$ and heated again to near dryness; $1 \mathrm{~cm}^{3} \mathrm{HClO}_{4}$ was added, heated until the appearance of white fumes, and finally dissolved with $12 \mathrm{~N}$ $\mathrm{HC} 1$ and diluted to $25 \mathrm{~cm}^{3}$ with deionized water.

Between each successive extraction listed above [(ii) to (v)], the sample was centrifuged at 3,500 rpm for $15 \mathrm{~min}$. Additionally, the supernatant was filtered using $0.45-\mu \mathrm{m}$ filter paper prior to AAS analysis.

\subsection{Microbial analysis}

The postharvest soil in each pot was subjected to a microbial analysis to evaluate the effects of $\mathrm{BC}$ on the total microbial count in $\mathrm{BC}$-amended and $\mathrm{BC}$ unamended serpentine soil. A dilution series was prepared from $10^{-1}$ to $10^{-5}$, and each dilution was plated in nutrient agar (NA) and potato dextrose agar (PDA) media to determine the number of bacteria and fungi in soil, respectively. The NA and PDA plates were incubated at $37{ }^{\circ} \mathrm{C}$ in 24 and $72 \mathrm{~h}$, respectively. Finally, the number of colony forming units (CFU) was counted (Onipe and Adebayo 2011).

\subsection{Statistical analyses}

Statistical analyses were carried out to compare how different BC application rates were influencing the growth of plants and the accumulation of metals in plant tissues by using a one-way analysis of variance (ANOVA) followed by Fisher's test $(p<0.05)$ for multiple comparisons. Mean separation procedure (least significant different test) and group comparisoncontrast were used after performing the ANOVA for randomized complete block designs (RCBD). All statistical analyses were carried out using Statistical software package (SAS 9.1). 


\section{Results and discussion}

3.1 Influence of biochar amendments on changes in soil $\mathrm{pH}$, EC, TOC, and CEC

The $\mathrm{pH}, \mathrm{EC}$, TOC, and CEC of serpentine soil increased significantly with the increasing concentration of $\mathrm{BC}$ amendment (Table 3). The increase in soil $\mathrm{pH}$ after the addition of $\mathrm{BC}$ is due to the alkali nature of the $\mathrm{BC}$. The dissolution of oxides, hydroxides, and carbonates of alkaline substances, decarboxylation of organic anions, and the ammonification of the soil provide nutrients for plant growth (Houben et al. 2013b) as well as the increase in soil $\mathrm{pH}$ may minimize the bioavailability of heavy metals in soil (Gall and Rajakaruna 2013; Neilson and Rajakaruna 2014). The TOC also increased significantly with the application of $\mathrm{BC}$ due to the addition of high carbon into the soil. The content of TOC in $5 \% \mathrm{BC}$ amended soil was twice as much as in the BC-unamended soil (Table 3).

The addition of $\mathrm{BC}$ significantly increased the soil CEC. This increase of soil CEC in the presence of $\mathrm{BC}$ is corroborated by earlier findings (Houben et al. 2013b; Karami et al. 2011). A significant increase in available nutrients was observed with increasing BC application rates (Table 3). Calcium increased the most after the addition of $\mathrm{BC}$ to serpentine soil. Given that $\mathrm{Ca}$ is often considered to be the most limiting nutrient for plant growth in serpentine soil (O'Dell and Rajakaruna 2011; Rajakaruna et al. 2012), this observed increase in response to $\mathrm{BC}$ application is worthy of note. The available amounts of $\mathrm{K}, \mathrm{Ca}$, and $\mathrm{Mg}$ in the $5 \% \mathrm{BC}$ amendment were multiplied by $1.2-2.0$-fold compared to the $\mathrm{BC}$-unamended soil. The increase in available nutrient content with increasing $\mathrm{BC}$ application rates results from free bases such as $\mathrm{K}^{+}, \mathrm{Ca}^{2+}$, and $\mathrm{Mg}^{2+}$ present in $\mathrm{BC}$ releasing into the soil solution, thereby increasing the $\mathrm{pH}$ of the soil and providing readily available nutrients for plant growth (Houben et al. 2013a).

\subsection{Effects of biochar on the growth of plants}

Tomato plants grown in BC-unamended serpentine soil displayed low biomass production compared to the plants that had received 1, 2.5, and $5 \% \mathrm{BC}$ application rates (Fig. 2). Three weeks after sowing, signs of metal toxicity in the aboveground parts of tomato plants were apparent in the $\mathrm{BC}$-unamended serpentine soil, and after the first harvest, plants were not able to survive any longer in the BCunamended soil. The common diagnostic symptoms of heavy metal phytotoxicity such as leaf chlorosis, necrosis, leaf epinasty, and growth retardation were displayed in plants that grew in the BC-unamended soil. Such symptoms are usual for tomato plants exposed to heavy metal stress, and metal toxicity symptoms have been previously documented (Moral et al. 1995).

Figure 3 depicts the variation of dry biomass of tomato plants grown in $\mathrm{BC}$-amended and $\mathrm{BC}$-unamended serpentine soil across successive harvests. There was a significant increase in the biomass of tomato plants with increasing BC concentrations across consecutive harvests (Table 4). The biomass of tomatoes grown in BC-unamended serpentine soil was reduced by $97 \%$ in the second harvest compared to the plants that had received $5 \% \mathrm{BC}$ application. This biomass reduction could be due to the bioaccumulation of heavy metals and the resulting phytotoxicity inhibiting the growth of plants. Overall, $5 \% \mathrm{BC}$ application in serpentine soil resulted in increasing the biomass of tomato plants by 40 fold compared to the BC-unamended soil. Such an increase in biomass production of tomato plants after addition of $\mathrm{BC}$ to serpentine soil could be due to both its fertilizing effect and the immobilization of heavy metals in serpentine soil. However, the plant tissues analyses data (Fig. 5) demonstrated that the addition of $\mathrm{BC}$ to serpentine soil had mostly contributed to the promotion of plant growth while enhancing the fertilizing effects. Moreover, these findings agree with those of recent studies (Houben et al. 2013a) confirming higher plant productivity when $\mathrm{BC}$ is applied, likely resulting from the immobilization of heavy metals in contaminated soil.

Table 3 Effects of different BC application rates on changes in $\mathrm{pH}, \mathrm{EC}$, TOC, and CEC of serpentine soil

\begin{tabular}{|c|c|c|c|c|c|}
\hline & & Control & $1 \% \mathrm{~B}+\mathrm{S}$ & $2.5 \% \mathrm{~B}+\mathrm{S}$ & $5 \% \mathrm{~B}+\mathrm{S}$ \\
\hline $\mathrm{pH}$ & & $5.5 \pm 0.06 \mathrm{~d}$ & $6.3 \pm 0.08 \mathrm{c}$ & $6.5 \pm 0.03 b$ & $7.6 \pm 0.01 \mathrm{a}$ \\
\hline EC & $\mu \mathrm{S} \mathrm{cm}{ }^{-1}$ & $120.1 \pm 0.12 \mathrm{a}$ & $71.4 \pm 0.08 \mathrm{~d}$ & $94.9 \pm 0.15 \mathrm{c}$ & $100.1 \pm 0.17 \mathrm{~b}$ \\
\hline TOC & $\mathrm{mg} \mathrm{g}^{-1}$ & $115.0 \pm 0.05 \mathrm{~d}$ & $129.5 \pm 0.11 \mathrm{c}$ & $148.4 \pm 0.18 b$ & $224.3 \pm 0.15 \mathrm{a}$ \\
\hline CEC & $\mathrm{cmol} \mathrm{kg}^{-1}$ & $3.4 \pm 0.08 \mathrm{~d}$ & $3.7 \pm 0.01 \mathrm{c}$ & $4.0 \pm 0.07 \mathrm{~b}$ & $4.3 \pm 0.03 \mathrm{a}$ \\
\hline Available K & $\mathrm{mg} \mathrm{kg}^{-1}$ & $650.0 \pm 0.17 \mathrm{~d}$ & $777.7 \pm 0.08 \mathrm{c}$ & $1,044.3 \pm 0.14 \mathrm{~b}$ & $1,294.3 \pm 0.09 \mathrm{a}$ \\
\hline Available $\mathrm{Ca}$ & $\mathrm{mg} \mathrm{kg}^{-1}$ & $2,527.5 \pm 0.06 \mathrm{~d}$ & $3,721.9 \pm 0.16 \mathrm{a}$ & $3,633.0 \pm 0.07 b$ & $3,521.9 \pm 0.19 \mathrm{c}$ \\
\hline Available Mg & $\mathrm{mg} \mathrm{kg}^{-1}$ & $899.3 \pm 0.11 \mathrm{~d}$ & $1,037.8 \pm 0.15 \mathrm{c}$ & $1,215.7 \pm 0.08 \mathrm{a}$ & $1,087.8 \pm 0.16 b$ \\
\hline
\end{tabular}

Control-BC-unamended soil, $1 \% \mathrm{~B}+\mathrm{S}-1 \% \mathrm{BC}$-amended soil, $2.5 \% \mathrm{~B}+\mathrm{S}-2.5 \% \mathrm{BC}$-amended soil, $5 \% \mathrm{~B}+\mathrm{S}-5 \% \mathrm{BC}$-amended soil. For each parameter, column means with the same letter do not differ significantly at the $5 \%$ level according to the Fisher's multiple-comparison test 


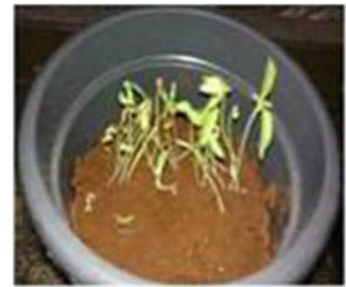

Control

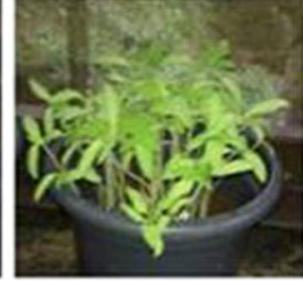

$1 \% \mathrm{BC}$

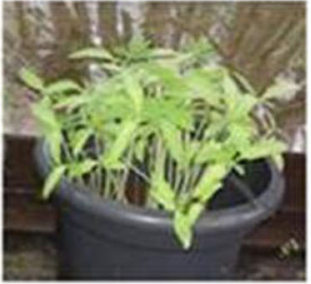

$2.5 \% \mathrm{BC}$

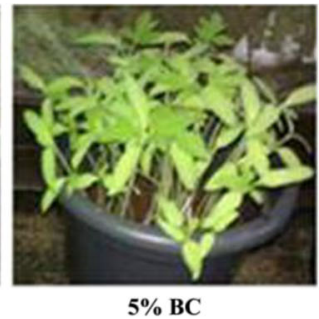

Fig. 2 Representative image showing differences in tomato plant growth 4 weeks after sowing. From left to right: BC-unamended soil, $1 \%$ BCamended soil, $2.5 \%$ BC-amended soil, and $5 \%$ BC-amended soil. Only one of the three replicates is shown for each treatment

\subsection{Effects of biochar on microbial growth}

The influence of $\mathrm{BC}$ as a soil amendment on changes in microbial quantity in serpentine soil is also of particular concern. No considerable difference was observed for the amount of bacteria and fungi between $1 \% \mathrm{BC}$ application and control. The maximum number of CFU was found in $2.5 \% \mathrm{BC}$ application, whereas $5 \% \mathrm{BC}$ showed a reduction in $\mathrm{CFU}$ (Fig. 4). This positive effect may be attributed to a general improvement in physical and chemical characteristics of the $2.5 \% \mathrm{BC}$ application. The pores in $\mathrm{BC}$ may provide a suitable habitat for microorganisms by protecting them from predation and drying while providing nutrients (Janice and Rillig 2009). Several recent studies have shown that BC is capable of stimulating the activity of agriculturally important soil microorganisms (Pietikäinen et al. 2000). Even though the increment of BC application increases the quality of soil physicochemical properties (Janice and Rillig 2009), infinite increase in $\mathrm{BC}$ application would not be beneficial for the biological activities in soil. Hence, a reduction in the CFU was observed in $5 \% \mathrm{BC}$ application. This could be due to the changes in soil structural properties and the adsorption of extracellular enzymes and inorganic nutrients to BC surface (Janice and Rillig 2009). Moreover, high cation exchange capacity and high density of functional groups in the $5 \%$ $\mathrm{BC}$ amendment may enhance the binding capacity of important macronutrients such as nitrogen and phosphorus, negatively impacting microbial growth (Gomez et al. 2014).

\subsection{Effects of biochar on uptake of heavy metals in Tomato} plants

The effects of $\mathrm{BC}$ on bioaccumulation of $\mathrm{Cr}, \mathrm{Ni}$, and $\mathrm{Mn}$ in tomato plants grown in $\mathrm{BC}$-amended and $\mathrm{BC}$-unamended
Fig. 3 Effects of $\mathrm{BC}$ on the growth of tomato plants in serpentine soil. For each harvest, means topped with the same letter do not differ significantly at the $5 \%$ level according to the Fisher's multiple-comparison test

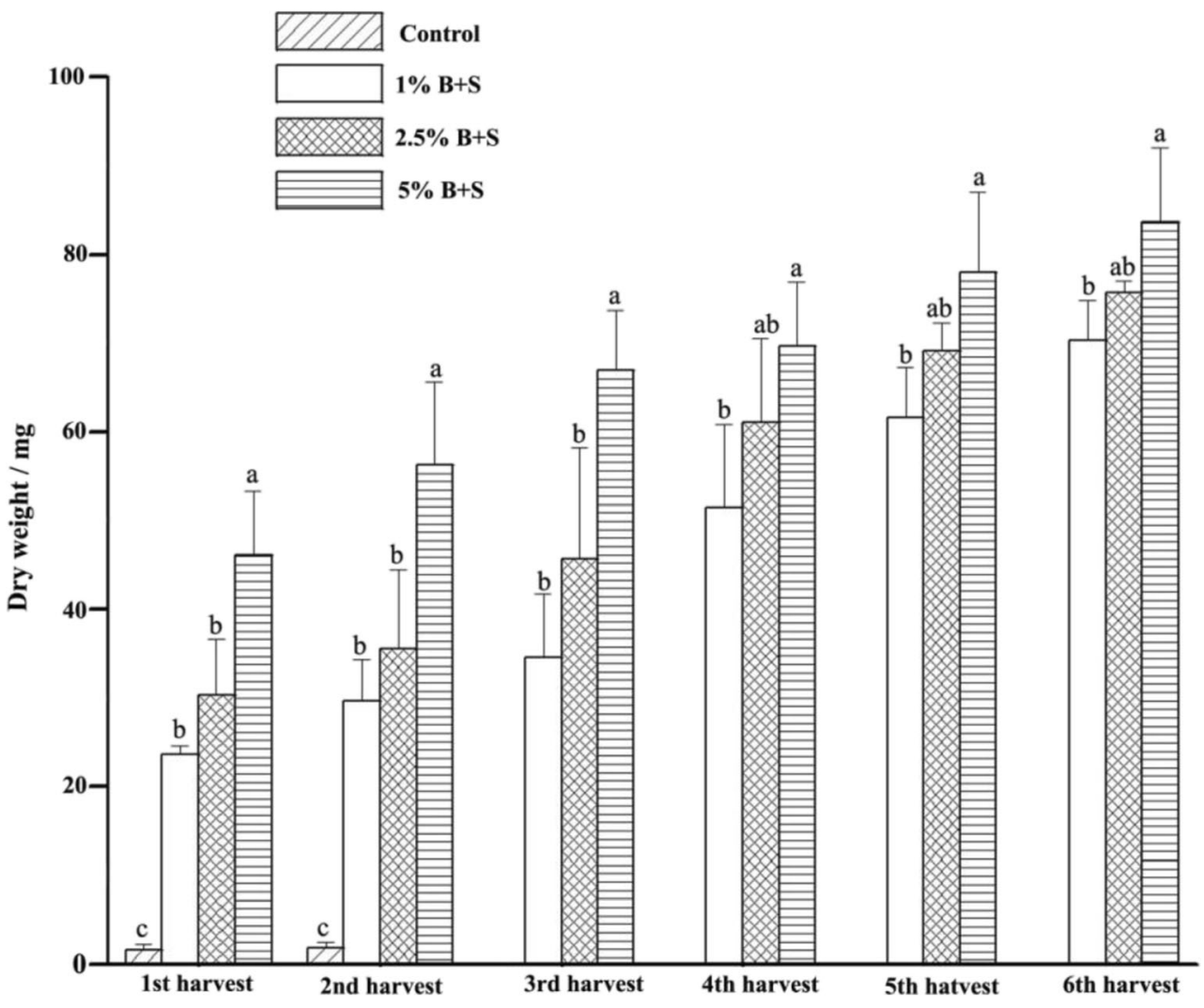


Table 4 Comparison of the biomass of tomato plants and accumulated concentrations of heavy metals in plant tissues due to the influence of different $\mathrm{BC}$ application rates

\begin{tabular}{|c|c|c|c|c|c|}
\hline & \multirow[t]{2}{*}{ Treatment } & \multirow[t]{2}{*}{ Biomass per plant/mg } & \multicolumn{3}{|c|}{ Total metal concentration $\left(\mathrm{mg} \mathrm{kg}^{-1}\right)$} \\
\hline & & & $\mathrm{Ni}$ & $\mathrm{Cr}$ & $\mathrm{Mn}$ \\
\hline \multirow[t]{4}{*}{ 1st harvest } & Control & $1.7 \pm 0.6 \mathrm{c}$ & $1,646.2 \pm 73.8 \mathrm{a}$ & $832.9 \pm 21.4 \mathrm{a}$ & $258.0 \pm 20.3 \mathrm{a}$ \\
\hline & $1 \% \mathrm{~B}+\mathrm{S}$ & $23.6 \pm 1.1 \mathrm{~b}$ & $293.8 \pm 20.4 b$ & $88.7 \pm 9.7 b$ & $185.6 \pm 12.8 \mathrm{~b}$ \\
\hline & $2.5 \% \mathrm{~B}+\mathrm{S}$ & $30.3 \pm 6.3 b$ & $238.6 \pm 21.0 \mathrm{~b}$ & $39.6 \pm 22.7 \mathrm{c}$ & $99.3 \pm 19.8 \mathrm{c}$ \\
\hline & $5 \% \mathrm{~B}+\mathrm{S}$ & $46.0 \pm 7.2 \mathrm{a}$ & $131.4 \pm 26.0 \mathrm{c}$ & $10.8 \pm 0.9 \mathrm{c}$ & $16.7 \pm 4.3 \mathrm{~d}$ \\
\hline \multirow[t]{4}{*}{ 2nd harvest } & Control & $1.9 \pm 0.6 \mathrm{c}$ & $1,898.8 \pm 58.0 \mathrm{a}$ & $3,087.3 \pm 157.0 \mathrm{a}$ & $813.0 \pm 82.6 \mathrm{a}$ \\
\hline & $1 \% \mathrm{~B}+\mathrm{S}$ & $29.5 \pm 4.7 b$ & $323.3 \pm 33.0 \mathrm{~b}$ & $337.7 \pm 56.3 b$ & $267.0 \pm 30.4 b$ \\
\hline & $2.5 \% \mathrm{~B}+\mathrm{S}$ & $35.4 \pm 9.0 \mathrm{~b}$ & $243.1 \pm 16.4 \mathrm{c}$ & $204.0 \pm 2.4 b c$ & $155.7 \pm 21.0 \mathrm{c}$ \\
\hline & $5 \% \mathrm{~B}+\mathrm{S}$ & $56.3 \pm 9.4 \mathrm{a}$ & $132.4 \pm 14.6 \mathrm{~d}$ & $88.3 \pm 12.0 \mathrm{c}$ & $58.3 \pm 9.7 d$ \\
\hline \multirow[t]{3}{*}{ 3rd harvest } & $1 \% \mathrm{~B}+\mathrm{S}$ & $34.5 \pm 7.2 b$ & $306.7 \pm 15.6 \mathrm{a}$ & $549.0 \pm 43.9 \mathrm{a}$ & $162.6 \pm 22.2 \mathrm{a}$ \\
\hline & $2.5 \% \mathrm{~B}+\mathrm{S}$ & $45.7 \pm 12.5 b$ & $203.3 \pm 21.3 b$ & $235.3 \pm 51.1 \mathrm{~b}$ & $130.7 \pm 5.0 \mathrm{~b}$ \\
\hline & $5 \% \mathrm{~B}+\mathrm{S}$ & $67.0 \pm 6.8 \mathrm{a}$ & $137.7 \pm 24.4 \mathrm{c}$ & $121.0 \pm 43.0 \mathrm{c}$ & $80.3 \pm 3.9 \mathrm{c}$ \\
\hline \multirow[t]{3}{*}{ 4th harvest } & $1 \% \mathrm{~B}+\mathrm{S}$ & $51.4 \pm 9.4 \mathrm{~b}$ & $354.3 \pm 33.6 \mathrm{a}$ & $169.3 \pm 19.8 \mathrm{a}$ & $172.3 \pm 12.0 \mathrm{a}$ \\
\hline & $2.5 \% \mathrm{~B}+\mathrm{S}$ & $61.0 \pm 9.5 \mathrm{ab}$ & $257.3 \pm 31.4 b$ & $103.7 \pm 10.1 b$ & $140.6 \pm 3.7 b$ \\
\hline & $5 \% \mathrm{~B}+\mathrm{S}$ & $69.7 \pm 7.2 \mathrm{a}$ & $134.0 \pm 12.0 \mathrm{c}$ & $54.7 \pm 8.0 \mathrm{c}$ & $73.3 \pm 17.1 \mathrm{c}$ \\
\hline \multirow[t]{3}{*}{ 5th harvest } & $1 \% \mathrm{~B}+\mathrm{S}$ & $61.7 \pm 5.6 b$ & $386.0 \pm 26.2 \mathrm{a}$ & $304.0 \pm 60.2 \mathrm{a}$ & $203.3 \pm 23.1 \mathrm{a}$ \\
\hline & $2.5 \% \mathrm{~B}+\mathrm{S}$ & $69.2 \pm 3.2 \mathrm{ab}$ & $268.7 \pm 41.1 b$ & $256.7 \pm 25.1 \mathrm{a}$ & $181.3 \pm 16.1 \mathrm{a}$ \\
\hline & $5 \% \mathrm{~B}+\mathrm{S}$ & $78.0 \pm 8.9 \mathrm{a}$ & $139.9 \pm 11.2 \mathrm{c}$ & $81.0 \pm 9.8 \mathrm{~b}$ & $96.6 \pm 6.1 \mathrm{~b}$ \\
\hline \multirow[t]{3}{*}{ 6th harvest } & $1 \%+S$ & $70.4 \pm 4.5 b$ & $382.2 \pm 9.4 \mathrm{a}$ & $347.0 \pm 21.0 \mathrm{a}$ & $184.6 \pm 2.0 \mathrm{a}$ \\
\hline & $2.5 \% \mathrm{~B}+\mathrm{S}$ & $75.7 \pm 1.4 \mathrm{ab}$ & $255.5 \pm 26.3 b$ & $232.3 \pm 31.4 b$ & $115.6 \pm 13.8 \mathrm{~b}$ \\
\hline & $5 \% \mathrm{~B}+\mathrm{S}$ & $83.6 \pm 8.4 \mathrm{a}$ & $142.7 \pm 5.4 \mathrm{c}$ & $106.0 \pm 17.9 \mathrm{c}$ & $70.0 \pm 7.5 \mathrm{c}$ \\
\hline
\end{tabular}

Control-BC-unamended soil, $1 \% \mathrm{~B}+\mathrm{S}-1 \% \mathrm{BC}$-amended soil, $2.5 \% \mathrm{~B}+\mathrm{S}-2.5 \% \mathrm{BC}$-amended soil, $5 \% \mathrm{~B}+\mathrm{S}-5 \% \mathrm{BC}$-amended soil. For each harvest, column means with the same letter do not differ significantly at the $5 \%$ level according to the Fisher's multiple-comparison test

serpentine soils across six successive harvests are depicted in Fig. 5. Consecutive harvesting was conducted on monitoring metal ions to assess the variation of accumulated concentrations of heavy metals in plant tissues with respect to growing time. All BC applications significantly reduced the uptake and bioaccumulation of $\mathrm{Cr}, \mathrm{Ni}$, and $\mathrm{Mn}$ across all
Fig. 4 Total number of bacteria and fungi per gram of soil in different $\mathrm{BC}$ application rates. For each harvest, means topped with the same letter do not differ significantly at the $5 \%$ level according to the Fisher's multiple-comparison test

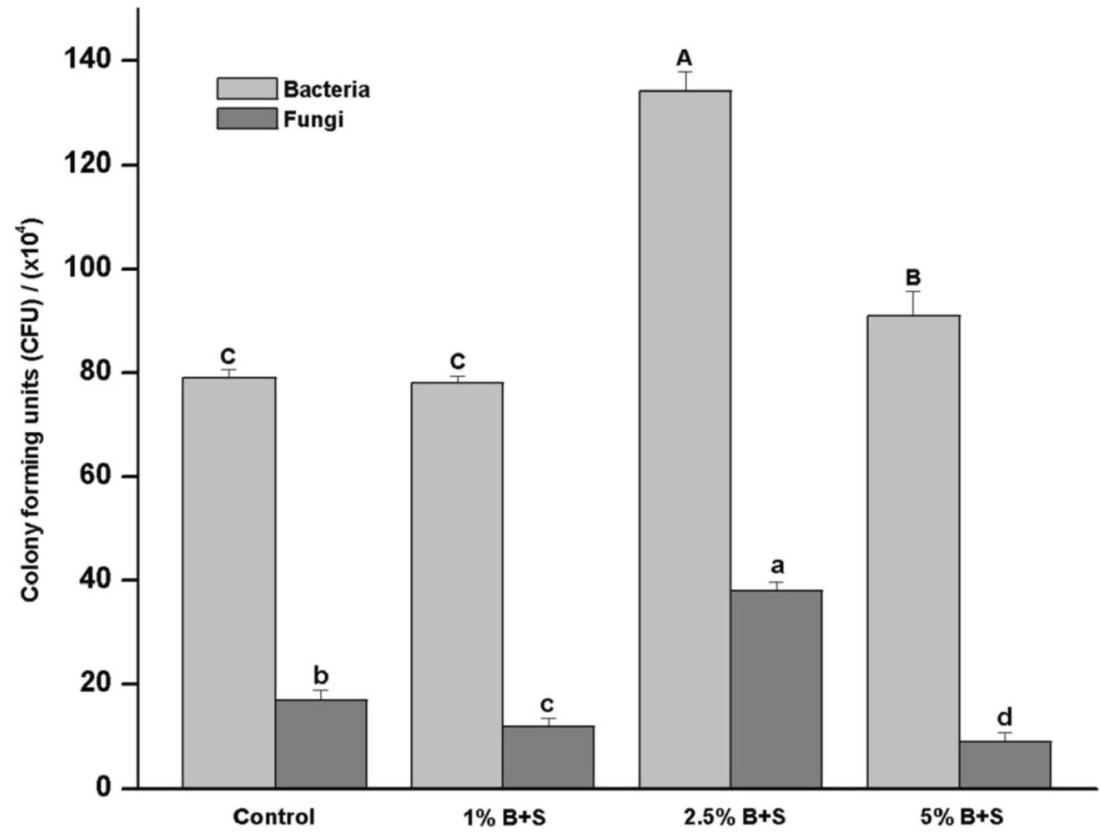


Fig. 5 Accumulated concentrations of a $\mathrm{Ni}, \mathbf{b} \mathrm{Mn}$, and c $\mathrm{Cr}$ in tomato plants grown on $\mathrm{BC}$-amended and BC-unamended serpentine soil across six consecutive harvests. For each harvest, means topped with the same letter do not differ significantly at the $5 \%$ level according to the Fisher's multiple-comparison test
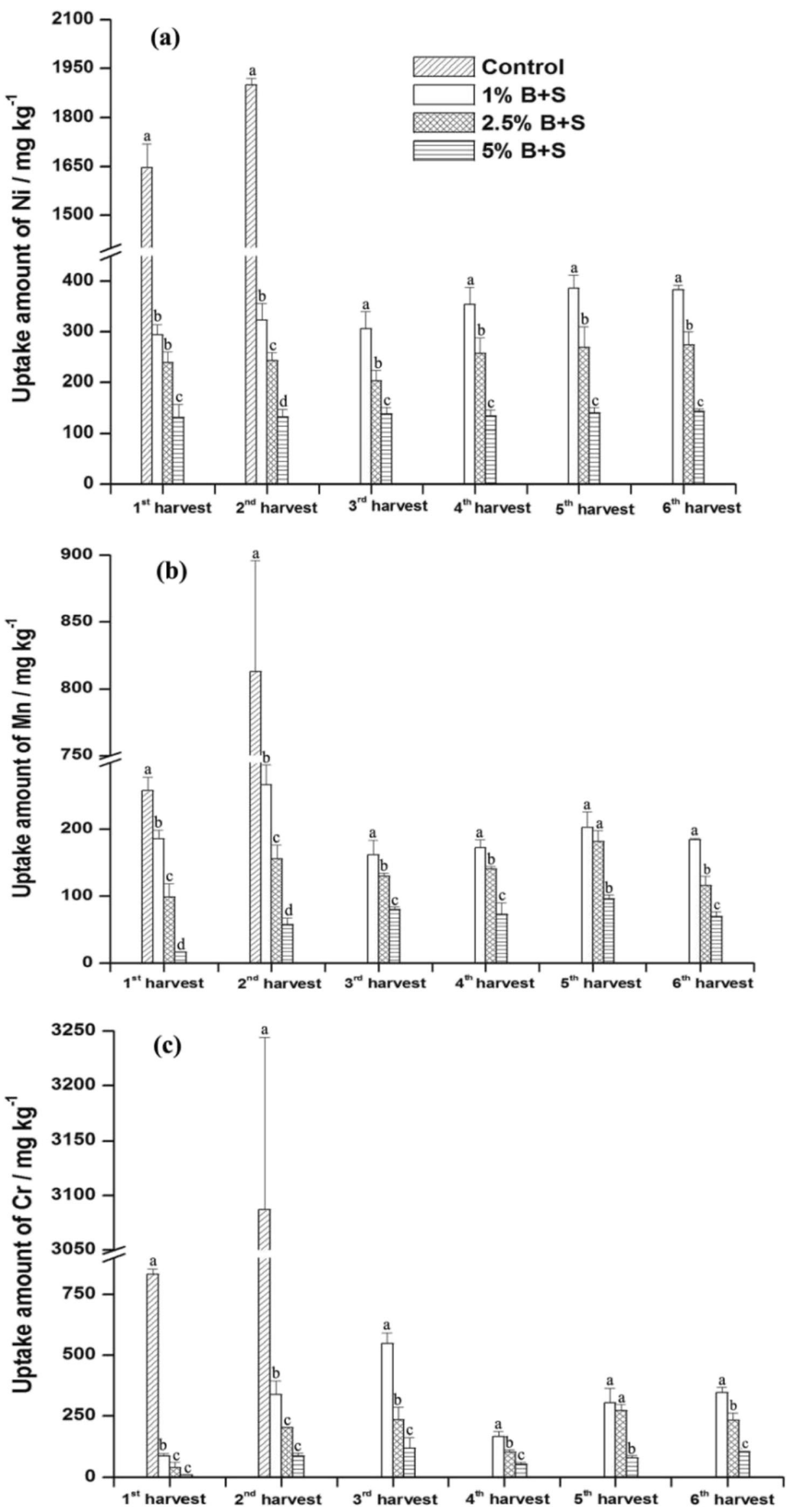
harvests (Table 4), and maximum accumulated concentrations of metals were found in tomato plants grown in $\mathrm{BC}$ unamended soil. Compared to the control, $1 \% \mathrm{BC}$ treatment reduced the accumulation of $\mathrm{Cr}, \mathrm{Ni}$, and $\mathrm{Mn}$ by 83,89 , and $67 \%$, respectively. In the presence of $2.5 \% \mathrm{BC}$ treatment, the reduction percentage increased up to 87,93 , and $81 \%$, whereas in the presence of $5 \% \mathrm{BC}$ treatment, it increased, reaching up to 93,97 , and $92 \%$, respectively. Overall, the bioaccumulation of $\mathrm{Cr}, \mathrm{Ni}$, and $\mathrm{Mn}$ in tomato plants grown in $\mathrm{BC}$ unamended soil was 14-35-fold higher than that of $5 \% \mathrm{BC}$ amended soil. Because of such high bioaccumulation of $\mathrm{Cr}$, $\mathrm{Ni}$, and $\mathrm{Mn}$, tomato plants grown in $\mathrm{BC}$-unamended serpentine soil were not able to survive the duration of the experiment due to metal-induced phytotoxicity. Meanwhile, the accumulation of these metals in tomato plants with consecutive harvesting is also of particular concern in order to assess the variation of bioaccumulation as a function of growing time. Although the accumulation of $\mathrm{Ni}$ in plants grown in BC-unamended soil in the second harvest was almost same as the first harvest, the accumulated concentrations of $\mathrm{Cr}$ and $\mathrm{Mn}$ were 3-4-fold higher than that of in the first harvest. Whereas, the bioaccumulation of these metals in plants that grew in BCamended soil was not significant $(p>0.05)$ with consecutive harvests. Hence, this suggests that the bioaccumulation of $\mathrm{Cr}$ and $\mathrm{Mn}$ in tomato plants tends to increase with time, and $\mathrm{Cr}$ and $\mathrm{Mn}$ could have the most detrimental effect on growth of tomato plants in BC-unamended soil.

The permissible limit values of $\mathrm{Ni}$ and $\mathrm{Cr}$ in plants recommended by WHO are 10 and $1.3 \mathrm{mg} / \mathrm{kg}$, respectively. Accumulation of excessive amounts of $\mathrm{Ni}$ and $\mathrm{Cr}$ is believed to interfere with $\mathrm{Fe}$ uptake and metabolism causing chlorosis and necrosis in plants (Ghani 2011; Khalid and Tinsley 1980). Therefore, the bioaccumulation of such high concentrations of $\mathrm{Cr}$ and $\mathrm{Ni}$ resulted in decreasing biomass and the occurrence of visible signs of metal toxicity in the aboveground parts of tomato plants grown in BC-unamended soil. Ghani (2011) found that the increase in the concentration of $\mathrm{Cr}$ in soil from $10-40 \mathrm{mg} / \mathrm{kg}$ is accompanied by the alteration of nutrient uptake in Brassica juncea shoots, thereby causing chlorosis. In our study, Mn was relatively less concentrated in plant tissues compared to other metals, suggesting that both $\mathrm{Ni}$ and $\mathrm{Cr}$ were the toxic elements that were predominantly responsible for the death of tomato plants grown in $\mathrm{BC}$ unamended soil.

The reduction of accumulated concentrations in plants that had received different $\mathrm{BC}$ application rates was due to greater immobilization of $\mathrm{Cr}, \mathrm{Ni}$, and $\mathrm{Mn}$ in serpentine soil via sorption and adsorption mechanisms. The capability of retention of these metals in mesopores of the $\mathrm{BC}$ could be increased with $\mathrm{BC}$ application rates. Therefore, the reduction of toxic levels of these heavy metals in the presence of $\mathrm{BC}$ could be attributed to improving the patterns of essential nutrient uptake by tomato plants, resulting in high biomass production.
Hence, plant tissue analyses suggested that the higher biomass production in the presence of $5 \% \mathrm{BC}$ application was accompanied by the enhancement of soil fertility as well as the reduction in plant uptake of metal ions.

\subsection{Bioavailability of heavy metals}

Environmental risks associated with the presence of heavy metals in soils are mainly dependent on the bioavailability of metals (Houben et al. 2013a). The exchangeable fraction in sequential extractions is the fraction of the total amount of metals that can either be bioavailable or made available for uptake by plants. The $\mathrm{MgCl}_{2}$ extractable concentrations of $\mathrm{Cr}$, $\mathrm{Ni}$, and $\mathrm{Mn}$ in $\mathrm{BC}$-amended and $\mathrm{BC}$-unamended serpentine soils are depicted in Fig. 6. In sequential extractions, the exchangeable metal concentrations in different $\mathrm{BC}$ amendments showed a considerable decrease with increasing $\mathrm{BC}$ application rates. The pattern of individual $\mathrm{MgCl}_{2}$ extractable metal concentrations was thus $\mathrm{Ni}>\mathrm{Mn}>\mathrm{Cr}$ and hence, $\mathrm{Ni}$ showed the highest bioavailability in both $\mathrm{BC}$-amended and $\mathrm{BC}$-unamended soil. Compared to the control soil, $1 \% \mathrm{BC}$ application decreased the bioavailable concentrations of $\mathrm{Cr}$, $\mathrm{Ni}$, and Mn concentrations by 95,14 , and $19 \%$, respectively. In the presence of $2.5 \% \mathrm{BC}$ application, the reduction percentage increased reaching up to 96,36 , and $21 \%$, while in the presence of $5 \%$ BC application, it reached 99,61 , and $42 \%$ for $\mathrm{Cr}$, Ni, and $\mathrm{Mn}$, respectively. Hence, the bioavailability of $\mathrm{Cr}, \mathrm{Ni}$, and $\mathrm{Mn}$ appears to have been greatly influenced by the $\mathrm{BC}$ application rates with $\mathrm{BC}$ readily immobilizing metals in serpentine soil.

\subsection{Sequential extractions of $\mathrm{Ni}, \mathrm{Mn}$, and $\mathrm{Cr}$}

Sequentially extracted concentrations of $\mathrm{Ni}, \mathrm{Mn}$, and $\mathrm{Cr}$ from different fractions in $\mathrm{BC}$-amended and $\mathrm{BC}$-unamended serpentine soil are depicted in Fig. 6. The highest amount of $\mathrm{Cr}$ and $\mathrm{Ni}$ in both $\mathrm{BC}$-amended and $\mathrm{BC}$-unamended serpentine soil was found to be in the residual fraction, whereas Mn was dominantly bound in the $\mathrm{Fe}-\mathrm{Mn}$ oxide phase. Fe-Mn oxide fraction is a major source of $\mathrm{Mn}$ in serpentine soil (Rajapaksha et al. 2012; Vithanage et al. 2014a). The application of $5 \%$ BC treatment to serpentine soil reduced the fraction of $\mathrm{Cr}, \mathrm{Ni}$, and $\mathrm{Mn}$ in $\mathrm{Fe}-\mathrm{Mn}$ oxide phase by 67,27 , and $43 \%$ respectively, compared to the BC-unamended soil. The residual fraction is associated with silicates as well as with other primary oxides such as spinels (Rajapaksha et al. 2012). Ni was dominantly bound in all phases in serpentine soil other than that in the $\mathrm{Fe}-$ $\mathrm{Mn}$ oxide fraction, while $\mathrm{Mn}$ was dominant in the $\mathrm{Fe}-\mathrm{Mn}$ oxide fraction of both $\mathrm{BC}$-amended and $\mathrm{BC}$-unamended serpentine soil. Such a reduction of available $\mathrm{Cr}, \mathrm{Ni}$, and $\mathrm{Mn}$ found in different phases after addition of $\mathrm{BC}$ to serpentine soil could be due to diffusion and adsorption phenomena. Adsorption of these metals onto $\mathrm{BC}$ could be in part explained 
Fig. 6 Effects of $\mathrm{BC}$ on $\mathbf{a ~ N i , ~} \mathbf{b}$ $\mathrm{Mn}$, and $\mathbf{c} \mathrm{Cr}$ fractions in the phases of exchangeable, carbonate bound, $\mathrm{Fe}-\mathrm{Mn}$ oxide bound, organic matter bound, and residual of serpentine soil. For each harvest, means topped with the same letter do not differ significantly at the $5 \%$ level according to the Fisher's multiple-comparison test
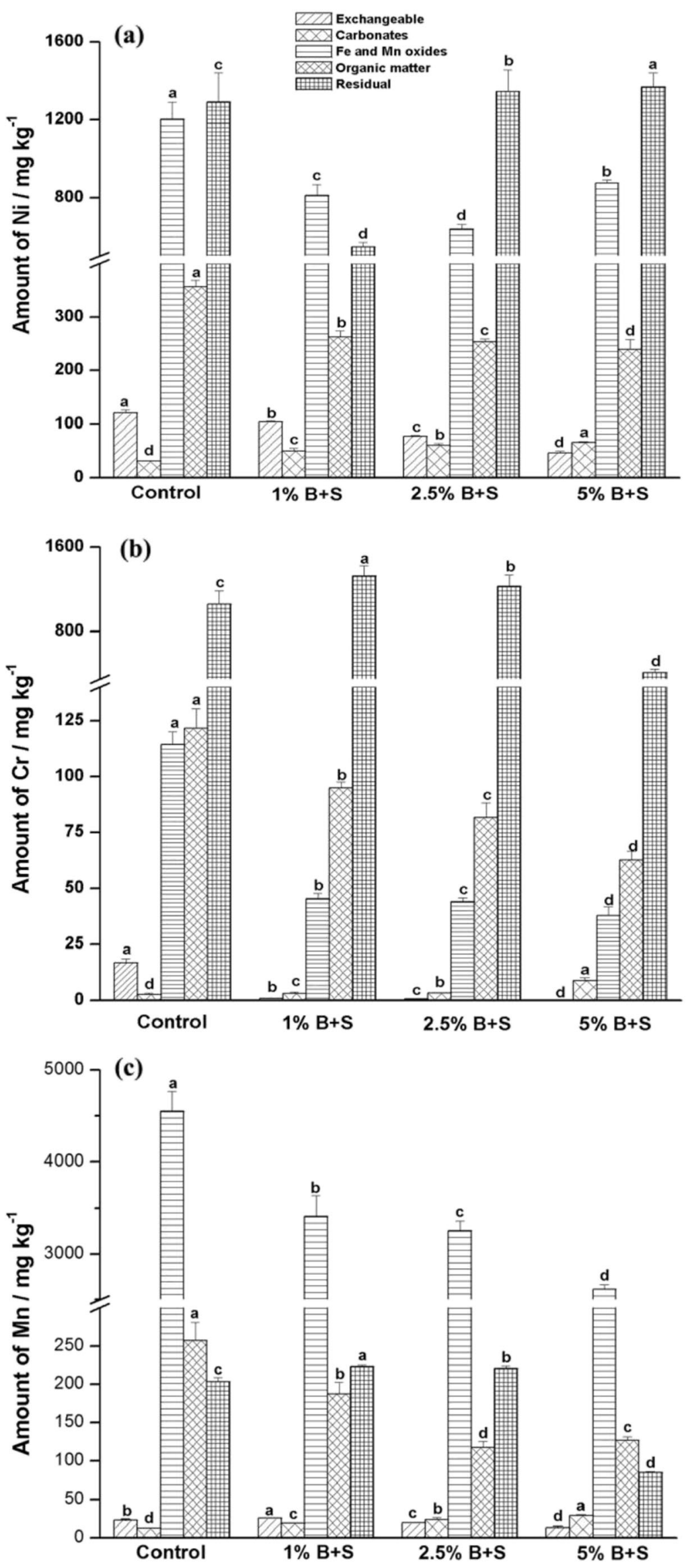
by its high surface area $\left(714 \mathrm{~m}^{2} / \mathrm{g}\right)$ and pore size $(40.8 \AA)$. The diffusion rate of the metals is being governed by $\mathrm{BC}$ pore size, and mesopores are highly available for adsorbing metals due to the lack of many surface functional groups as indicated by the FTIR data. The higher attenuation of $\mathrm{Cr}$ in the presence of $5 \% \mathrm{BC}$ rate may be due to its smaller ionic radius $(0.52 \AA)$ which favored its diffusion compared to that of $\mathrm{Ni}(0.69 \AA)$ and $\mathrm{Mn}(0.91 \AA)$. However, the adsorption may also be limited since organic substances such as humic acids present in the soil can readily be attached to the BC surface, rending inner pores unavailable for metal diffusion and further adsorption. Hence, further studies should be undertaken for better understanding the metal immobilization mechanisms in BCamended soils.

\section{Conclusions}

The present study was conducted to investigate the potential of woody BC, a waste byproduct of a bioenergy industry, as a soil amendment to immobilize bioavailable toxic metals and reduce the phytotoxicity of serpentine soil. Tomato plants grown in $5 \% \mathrm{BC}$-amended serpentine soil increased dry biomass by 30 -fold compared to the $\mathrm{BC}$-unamended soil. However, the highest bacterial and fungal counts were found in the $2.5 \% \mathrm{BC}$-amended soil. Bioaccumulation of $\mathrm{Cr}$, $\mathrm{Ni}$, and $\mathrm{Mn}$ in tomato plants grown in $5 \% \mathrm{BC}$-amended soil also decreased by $93-97 \%$ compared to the BC-unamended soil. Sequential extraction data demonstrated that the least exchangeable fraction of all the metals was in the $5 \% \mathrm{BC}$ amended serpentine soil, revealing that the reduction of exchangeable metal fractions is primarily due to the immobilization of $\mathrm{Cr}, \mathrm{Ni}$, and $\mathrm{Mn}$, thereby reducing their bioavailability. Hence, the present study contributes further evidence that the release of $\mathrm{Ni}, \mathrm{Cr}$, and $\mathrm{Mn}$ from serpentine soil and their bioavailability and phytotoxicity can be reduced with the increase in the $\mathrm{BC}$ application. Furthermore, the present study shows that the application of $\mathrm{BC}$ to heavy metal-rich sites, including areas that were formerly used for metal extraction, may immobilize metal translocation and accumulation in plants, including in agricultural crops. Hence, BC as a byproduct from the bioenergy industry may potentially be used in the restoration of heavy metal-contaminated soil.

\section{References}

Ahmad M, Lee SS, Dou X, Mohan D, Sung J-K, Yang JE, Ok YS (2012) Effects of pyrolysis temperature on soybean stover-and peanut shellderived biochar properties and TCE adsorption in water. Bioresour Technol 118:536-544
Ahmad M, Moon DH, Vithanage M, Koutsospyros A, Lee SS, Yang JE et al (2014) Production and use of biochar from buffalo-weed (Ambrosia trifida L.) for trichloroethylene removal from water. $\mathrm{J}$ Chem Technol Biotech 89:150-157

Ahmad M, Rajapaksha AU, Lim JE, Zhang M, Bolan N, Mohan D et al (2013) Biochar as a sorbent for contaminant management in soil and water: a review. Chemosphere 99:19-33

Almaroai YA, Usman AR, Ahmad M, Moon DH, Cho JS, Joo Y et al (2014) Effects of biochar, cow bone, and eggshell on $\mathrm{Pb}$ availability to maize in contaminated soil irrigated with saline water. Environ Earth Sci 71:1289-1296

Anderson B, de Peyster A, Gad SC (2005) Encyclopedia of toxicology. Elsevier, Amsterdam

Armienta M, Rodríguez R, Ceniceros N, Juarez F, Cruz O (1996) Distribution, origin and fate of chromium in soils in Guanajuato, Mexico. Environ Pollut 91:391-397

Baugé SMY, Lavkulich LM, Schreier HE (2013) Phosphorus and trace metals in serpentine-affected soils of the Sumas Basin, British Columbia. Can J Soil Sci 93:359-367

Beesley L, Marmiroli M, Pagano L, Pigoni V, Fellet G, Fresno T et al (2013) Biochar addition to an arsenic contaminated soil increases arsenic concentrations in the pore water but reduces uptake to tomato plants (Solanum lycopersicum L.). Sci Total Environ 454: 598-603

Chen B, Zhou D, Zhu L (2008) Transitional adsorption and partition of nonpolar and polar aromatic contaminants by biochars of pine needles with different pyrolytic temperatures. Environ Sci Technol 42:5137-5143

Fernández S, Seoane S, Merino A (1999) Plant heavy metal concentrations and soil biological properties in agricultural serpentine soils. Commun Soil Sci Plan 30:1867-1884

Gall JE, Rajakaruna N (2013) The physiology, functional genomics, and applied ecology of heavy metal-tolerant Brassicaceae. In: Lang M (ed) Brassicaceae: Characterization, Functional Genomics and Health Benefits. Nova, New York, pp 121-148

Ghani A (2011) Effect of chromium toxicity on growth, chlorophyll and some mineral nutrients of Brassica juncea L. Egypt Acad J Biol Sci 2:9-15

Gomez JD, Denef K, Stewart CE, Zheng J \& Cotrufo MF (2014) Biochar addition rate influences soil microbial abundance and activity in temperate soils. Eur J Soil Sci 65. doi:10.1111/ejss.12097

Houben D, Evrard L, Sonnet P (2013a) Beneficial effects of biochar application to contaminated soils on the bioavailability of $\mathrm{Cd}, \mathrm{Pb}$ and $\mathrm{Zn}$ and the biomass production of rapeseed (Brassica napus L.). Biomass Bioenerg 57:196-204

Houben D, Evrard L, Sonnet P (2013b) Mobility, bioavailability and pHdependent leaching of cadmium, zinc and lead in a contaminated soil amended with biochar. Chemosphere 92:1450-1457

Janice ET, Rillig MC (2009) Characteristics of biochar: biological properties. In: Lehmann J, Joseph S (eds) Biochar for environmental management: science and technology. Earthscan, London, pp 85102

Jiang W, Liu D, Hou W (2001) Hyperaccumulation of cadmium by roots, bulbs and shoots of garlic (Allium sativum L.). Bioresour Technol 76:9-13

Karami N, Clemente R, Moreno-Jiménez E, Lepp NW, Beesley L (2011) Efficiency of green waste compost and biochar soil amendments for reducing lead and copper mobility and uptake to ryegrass. J Hazard Mater 191:41-48

Kayama M, Sasa K, Koike T (2002) Needle life span, photosynthetic rate and nutrient concentration of Picea glehnii, P. jezoensis and P. abies planted on serpentine soil in northern Japan. Tree Physiol 22:707-716

Khalid BY, Tinsley J (1980) Some effects of nickel toxicity on rye grass. Plant Soil 55:139-144

Mebius LJ (1960) A rapid method for the determination of organic carbon in soil. Anal Chimi Acta 22:120-124 
Moral R, Pedreno JN, Gomez I, Mataix J (1995) Effects of chromium on the nutrient element content and morphology of tomato. J Plant Nutr 18:815-822

Mulligan CN, Yong RN, Gibbs BF (2001) Remediation technologies for metal-contaminated soils and groundwater: an evaluation. Eng Geol 60:193-207

Neilson S, Rajakaruna N (2014) Phytoremediation of agricultural soils: using plants to clean metal-contaminated arable lands. In: Ansari AA, Gill SS, Lanza GR (ed) Phytoremediation: management of environmental contaminants. Springer (in press)

O’Dell RE, Rajakaruna N (2011) Intraspecific variation, adaptation, and evolution. In: Harrison SP, Rajakaruna N (eds) Serpentine: evolution and ecology in a model system. University of California Press, California, pp 97-137

Onipe O, Adebayo A (2011) Bacteriological and mineral studies of road side soil samples in Ado-Ekiti metropolis, Nigeria. J Microbiol Biotechn Food Sci 1:247-266

Park JH, Choppala GK, Bolan NS, Chung JW, Chuasavathi T (2011) Biochar reduces the bioavailability and phytotoxicity of heavy metals. Plant Soil 348:439-451

Paz-Ferreiro J, Lu H, Fu S, Méndez A, Gascó G (2013) Use of phytoremediation and biochar to remediate heavy metal polluted soils: a review. Solid Earth Discus 5:2155-2179

Peterson SC, Jackson MA, Kim S, Palmquist DE (2012) Increasing biochar surface area: optimization of ball milling parameters. Powder Technol 228:115-120

Pietikäinen J, Kiikkilä O, Fritze H (2000) Charcoal as a habitat for microbes and its effect on the microbial community of the underlying humus. Oikos 89:231-242

Rajakaruna N, Baker AJM (2004) Serpentinine: a model habitat for botanical research in Sri Lanka. Ceylon J Sci 32:1-19

Rajakaruna N, Knudsen K, Fryday AM, O’Dell RE, Pope N, Olday FC, Woolhouse $S$ (2012) Investigation of the importance of rock chemistry for saxicolous lichen communities of the New Idria serpentinite mass, San Benito County, California, USA. Lichenologist 44:695-714

Rajakaruna N, Tompkins KM, Pavicevic PG (2006) Phytoremediation: an affordable green technology for the clean-up of metalcontaminated sites in Sri Lanka. Ceylon J Sci 35:25-39

Rajapaksha AU, Vithanage M, Oze C, Bandara W, Weerasooriya R (2012) Nickel and manganese release in serpentine soil from the Ussangoda Ultramafic Complex, Sri Lanka. Geoderma 189:1-9

Sruthy OA, Jayalekshmi S (2014) Electrokinetic remediation of heavy metal contaminated soil. Int J Struct \& Civil Engg 3

Summer ME, Andersen CP (1996) Methods of soil analysis. Journal, Soil Science Society of America

Sun K, Gao B, Ro KS, Novak JM, Wang Z, Herbert S, Xing B (2012) Assessment of herbicide sorption by biochars and organic matter associated with soil and sediment. Environ Pollut 163:167-173

Susaya J, Kim K-H, Asio V, Chen Z-S, Navarrete I (2010) Quantifying nickel in soils and plants in an ultramafic area in Philippines. Environ Monit Assess 167:505-514

Uchimiya M, Klasson KT, Wartelle LH, Lima IM (2011) Influence of soil properties on heavy metal sequestration by biochar amendment: 1 . Copper sorption isotherms and the release of cations. Chemosphere 82:1431-1437

Usman AR, Almaroai YA, Ahmad M, Vithanage M, Ok YS (2013) Toxicity of synthetic chelators and metal availability in poultry manure amended $\mathrm{Cd}, \mathrm{Pb}$ and $\mathrm{As}$ contaminated agricultural soil. J Hazard Mater 262:1022-1030

Vithanage M, Rajapaksha AU, Oze C, Rajakaruna N, Dissanayake C (2014a) Metal release from serpentine soils in Sri Lanka. Environ Monit Assess 186:3415-3429

Vithanage M, Rajapaksha AU, Tang X, Thiele-Bruhn S, Kim KH, Lee SE, Ok YS (2014b) Sorption and transport of sulfamethazine in agricultural soils amended with invasive-plant-derived biochar. J Environ Manage 141:95-103 